\title{
PERENCANAAN KONSTRUKSI DAN ELEMEN MESIN TURBIN ANGIN SUMBU VERTIKAL TYPE DARRIEUS
}

\author{
Diaurahman'), Rudi Siswanto²) \\ ${ }^{1,2}$ Program Studi Teknik Mesin \\ Fakultas Teknik Universitas Lambung Mangkurat \\ JL. Akhmad Yani Km.36 Banjarbaru, Kalimantan Selatan,70714 \\ Telp. 0511-4772646, Fax 0511-4772646 \\ E-mail : diaurahman@outlook.com
}

\begin{abstract}
Wind energi is one of the alternative energi that can be utilized for various purposes to replace the source of fossil fuel energi. The Darrieus wind turbine includes a vertikal axis wind turbine driven by lifting force from the blade. Planning of the axis vertikal type Darrieus wind turbine is aimed to calculate the elements of Darrieus machine and make design of vertikal axis component of Darrieus vertikal turbine using Marzuki (2016) research data about NACA 2415 blend analysis with variation of blade and angle of attack. The planning method used is based on the calculation of construction and vertikal axis of vertikal axis type of wind machine by using field result data in the form of wind speed, altitude and environmental condition which produce calculation result and working drawing of each machine element. The results of planning engine eleman on vertikal axis wind turbine Darrieus with 3 pieces airfoil shaped type NACA 2415 chord $30 \mathrm{~cm}$ has a diameter and height of 1 meter. Using ST-42 shaft $17-25 \mathrm{~mm}$ in diameter with length $1640 \mathrm{~mm}$ retained 2 bearing pieces with numbers 30203 and 6204. Transmission using belt and pulley type with 1: 14 increase ratio. Frame using Lx steel profile size 30x30 with total length $\pm 15 \mathrm{~m}$. The use of materials such as composites is preferable to reduce turbine load without affecting the strength and durability of the turbine.
\end{abstract}

Keywords: machine element, vertikal axis wind turbine, darrieus

\section{PENDAHULUAN}

Energi angin merupakan salah satu jenis energi alternatif yang dapat dimanfaatkan untuk menggantikan sumber energi berbahan bakar fosil. Salah satu pemanfaatan energi angin adalah penggunaan turbin angin yang banyak digunakan sebagai pembangkit listrik energi angin. Turbin angin yang dapat menghasilkan energi dari angin secara umum dapat diklasifikasikan menjadi dua yaitu turbin angin sumbu horizontal dan turbin angin sumbu vertikal. Turbin angin Darrieus termasuk jenis turbin angin sumbu vertikal yang digerakkan oleh gaya angkat dari sudu.

Hasil analisis dan pemetaan potensi energi angin di Indonesia, wilayah yang memiliki kecepatan angin rata-rata di atas $3 \mathrm{~m} / \mathrm{s}$ meliputi propinsi Aceh, Sumatera Utara, Sumatera Barat, Riau, Kepulauan Riau, Jambi, Lampung, DKI Jakarta, Banten, Jawa Barat, Jawa Tengah, Yogyakarta, Jawa Timur, Bali, NTB, NTT, Kalimantan Tengah, Kalimantan Selatan, Kalimantan Timur, Sulawesi Utara, Sulawesi Tengah, Sulawesi Barat, Sulawesi Selatan, Maluku, Maluku Utara, Papua Barat, dan Papua (Rachman, A 2012). Berdasarkan data Stasiun Pengamatan BMKG periode 2011 - 2015, Kalimantan Selatan memiliki kecepatan angin rata-rata $3.5 \mathrm{~m} / \mathrm{s}$ dengan kecepatan rata-rata tertinggi mencapai $5.3 \mathrm{~m} / \mathrm{s}$ pada tahun 2011 . 
Rancangan struktur yang baik dan komprehensif sangat menentukan usia dan kekuatan konstruksi terhadap beban-beban yang bekerja. Struktur juga harus dirancang untuk dapat menahan beban dari kejutan angin. Perhitungan struktur dapat dilakukan dengan mempertimbangkan semua gaya maksimum yang bekerja lalu menganalisisnya untuk setiap bagian atau komponen struktur.

Pada penelitian ini bertujuan untuk menghitung elemen-elemen mesin dan membuat design perencanaan komponen Turbin Angin Sumbu Vertikal Darrieus. Sehingga dilakukan penelitian dengan judul : "Perencanaan Konstruksi Dan Elemen Mesin Turbin Angin Sumbu Vertikal Type Darrieus" yang dirancang dengan aspek sederhana, portable dan ekonomis.

\section{Angin}

Perbedaan tekanan udara di suatu wilayah serta adanya pengaruh dari rotasi bumi menyebabkan udara bergerak dari tekanan tinggi ke tekanan rendah. Udara yang bergerak dengan kecepatan tertentu disebut dengan angin. Angin merupakan suatu jenis fluida yang memiliki massa dan kecepatan yang mengandung energi kinetik. Energi tersebut sangat berpotensi untuk dimanfaatkan menjadi energi alternatif dengan mengubahnya menjadi energi mekanik hingga energi listrik.

Proses konversi energi tersebut dapat dilakukan dengan memanfaatkan sebuah sistem turbin angin yang kemudian dapat digunakan untuk menggerakkan pompa hingga membangkitkan energi listrik. Sehingga penggunaan energi angin dapat menjadi sebuah opsi dalam mengurangi ketergantungan terhadap energi dari bahan bakar fosil.

\section{Turbin Angin}

Sebuah kincir angin yang awalnya hanya dimanfaatkan untuk keperluan pertanian, kemudian dikembangkan menjadi salah satu penyedia atau penghasil energi listrik. Meskipun jumlah energi yang dihasilkan tidak terlalu besar jika dibandingkan dengan listrik dari PLTU.

Dalam pengembangannya, desain turbin angin semakin divariasi dengan tujuan untuk memperoleh tingkat aerodinamis yang tinggi sehingga menghasilkan efisiensi maksimal dalam proses konversi energi kinetik angin menjadi energi mekanik. Secara umum, ada dua klasifikasi turbin angin yang dibedakan berdasarkan arah rotasi atau sumbu rotasinya yaitu sumbu horizontal dan sumbu vertikal.

Dari sudut pandang efisiensi sumbu horizontal lebih diuntungkan dibandingkan sumbu vertikal karena dengan menggunakan menara yang tinggi dapat menjangkau kecepatan angin yang lebih besar dari angin permukaan. Akan tetapi sangat berisiko terjadi kerusakan jika menara tidak dapat menahan beban dari angin dengan kecepatan tinggi.

Pada sumbu vertikal meskipun memerlukan daya awal untuk memutar, namun memiliki torsi yang lebih besar dari sumbu horizontal. Wilayah perbukitan dengan permukaan savana sangat ideal karena turbin jenis ini memiliki konstruksi rendah yang lebih baik dalam menangkap angin permukaan.

Turbin angin sumbu vertikal dapat dibedakan lagi menjadi jenis Darrieus dan Savonius. Pada jenis Darrieus memanfaatkan gaya lift sedangkan jenis savonius memanfaatkan gaya drag. Perbedaan secara fisik dapat dilihat dari penggunaan lengan sudu pada Darrieus sedangkan savonius sudu menempel pada poros turbin. 


\section{Elemen Mesin Turbin Angin Sumbu Vertikal type Darrieus}

1. Poros

Pemilihan bahan poros sangat penting untuk menjaga poros agar mampu menahan beban yang terjadi dan menghindari dimensi yang terlalu besar. Untuk mengetahui sifat bahan poros dapat dilihat pada tabel di bawah ini.

Tabel 1. Sifat bahan poros berdasarkan JIS

\begin{tabular}{|c|c|c|c|c|}
\hline $\begin{array}{l}\text { Standar dan } \\
\text { macam }\end{array}$ & Lambang & $\begin{array}{l}\text { Perlakuan } \\
\text { panass }\end{array}$ & $\begin{array}{c}\text { Kekuatan } \\
\text { tarik } \\
(\mathrm{kg} / \mathrm{mm} 2)\end{array}$ & Keterangan \\
\hline \multirow{6}{*}{$\begin{array}{c}\text { Baja karbon } \\
\text { konstruksi mesin } \\
\text { (JIS G 4501) }\end{array}$} & S30C & Penormalan & 48 & \\
\hline & $\mathrm{S} 35 \mathrm{C}$ & " & 52 & \\
\hline & $\mathrm{S} 40 \mathrm{C}$ & $"$ & 55 & \\
\hline & $\mathrm{S} 45 \mathrm{C}$ & $"$ & 58 & \\
\hline & $\mathrm{S} 50 \mathrm{C}$ & $"$ & 62 & \\
\hline & $\mathrm{S} 55 \mathrm{C}$ & " & 66 & \\
\hline \multirow{3}{*}{$\begin{array}{l}\text { Batang bają yang } \\
\text { difinis dingin }\end{array}$} & S35C-D & - & 53 & \multirow{3}{*}{$\begin{array}{l}\text { ditarik dingin } \\
\text { digerinda } \\
\text { dibubut, atau } \\
\text { gabunngan antara } \\
\text { hal-hal tersebut }\end{array}$} \\
\hline & S45C-D & - & 60 & \\
\hline & S55C-D & - & 72 & \\
\hline
\end{tabular}

bahan.

Dalam pemilihan poros yang akan digunakan perlu diperhatikan faktor koreksi

Tabel 2. Faktor koreksi daya poros (Fc)

\begin{tabular}{|c|c|}
\hline Daya yang akan ditransmisikan & $\boldsymbol{f}_{\boldsymbol{c}}$ \\
\hline Daya rata-rata yang diperlukan & $1,2-2,0$ \\
\hline Daya Maksimum yang diperlukan & $0,8-1,2$ \\
\hline Daya normal & $1,0-1,5$ \\
\hline
\end{tabular}

2. Menghitung momen poros

$\mathrm{T}=9,74 \times 10^{5} \frac{\mathrm{P}_{\mathrm{d}}}{\mathrm{n}_{1}}$

dimana:

$P d=$ Daya rencana $(k W)$

$\mathrm{T}=$ momen puntir (kg.mm)

$\mathrm{n}_{1}=$ putaran (rpm)

3. Tegangan geser izin

$\tau_{a}=\frac{\sigma_{B}}{S f_{1} \times S f_{2}}$

dimana:

$\tau_{a}=$ tegangan geser izin $\left(\mathrm{kg} / \mathrm{mm}^{2}\right)$ 
$\sigma_{B}=$ kekuatan tarik $\left(\mathrm{Kg} / \mathrm{mm}^{2}\right)$

$S f_{1}=$ faktor koreksi beban puntir

$S f_{2}=$ faktor koreksi alur pasak

4. Diameter poros

$d_{s}=\left[\left(\frac{5,1}{\tau_{a}}\right) \cdot K_{t} \cdot C_{b} \cdot T\right]^{\frac{1}{3}}$

dimana :

$\tau_{a}=$ Tegangan geser izin $\left(\mathrm{Kg} / \mathrm{mm}^{2}\right)$

$C_{b}=$ faktor koreksi beban lentur

$K_{t}=$ Faktor koreksi torsi

$\mathrm{T}=$ Momen puntir (Kg.mm)

$K_{t}=$ Factor koreksi momen puntir

5. Bantalan

Dalam perencanaan bantalan dapat dilakukan dengan perhitungan:

a. Menentukan berat poros

$W_{p}=\rho_{p} . V_{p}$

dimana:

$W_{p}=$ berat poros

$\rho_{p}=$ Massa jenis bahan poros

$V_{p}=$ Volume poros

b. Beban equivalen yang diterima oleh bantalan

$\mathrm{W}_{\mathrm{e}}=\left(\mathrm{X}_{\mathrm{R}} \cdot \mathrm{v} \cdot \mathrm{W}_{\mathrm{R}}+\mathrm{Y}_{\mathrm{T}} \cdot \mathrm{W}_{\mathrm{T}}\right) \cdot \mathrm{Ks}$

dimana:

$W_{e}=$ beban equivalen yang diterima bantalan $(\mathrm{N})$

$X_{R}=$ faktor beban radial

$v=$ faktor putaran $=1$, untuk bagian dalam yang berputar

$W_{R}=$ beban radial pada bantalan

$Y_{T}=$ faktor untuk beban aksial

$W_{T}=$ beban aksial pada bantalan (N)

$K s=$ service faktor untuk beban kejut ringan $(1,5)$

C. Perhitungan umur bantalan

$L=60 \times n_{2} \times L_{H}$

dimana:

$\mathrm{L}$ = banyaknya putaran

$L_{H}=$ umur bantalan

$n_{2}=$ putaran poros $(\mathrm{rpm})$ 
6. Transmisi

Sistem transimisi yang digunakan pada perencanaan ini adalah transmisi sabuk dan pulley.

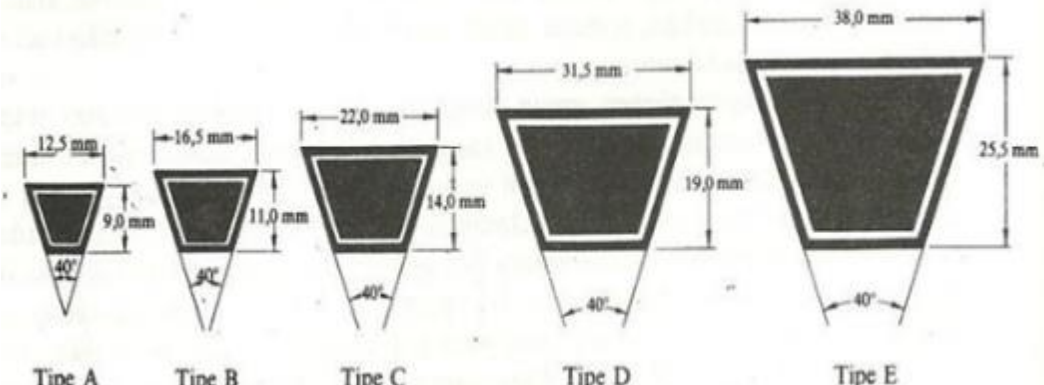

Gambar 1. Sabuk V

Jenis sabuk yang digunakan adalah sabuk $A$, karena daya yang diteruskan di bawah $1 \mathrm{~kW}$ dan dapat menahan putaran yang tinggi.

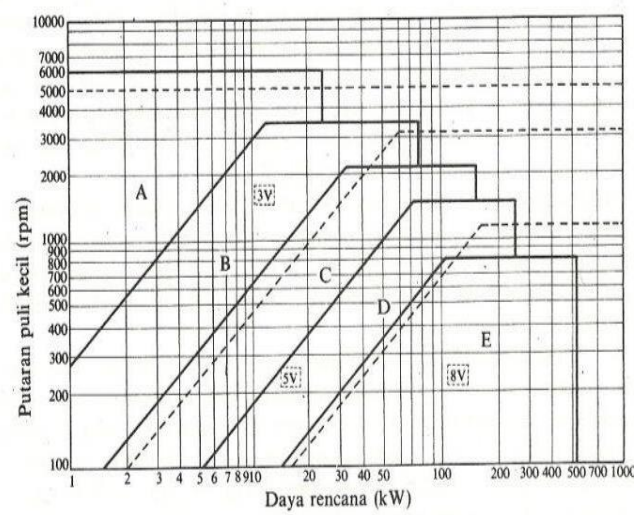

Gambar 2. Diagram Pemilihan Sabuk

\section{METODE PENELITIAN}

Perhitungan konstruksi dan elemen mesin dengan menggunakan data - data hasil di lapangan berupa kecepatan angin, ketinggian dan kondisi lingkungan sekitar. Hasil perencanaan terdiri dari data - data hasil perhitungan elemen mesin dan gambar kerja tiap elemen mesin. 
Diagram alir penelitian pada perencanaan ini dapat dilihat pada Gambar 3.
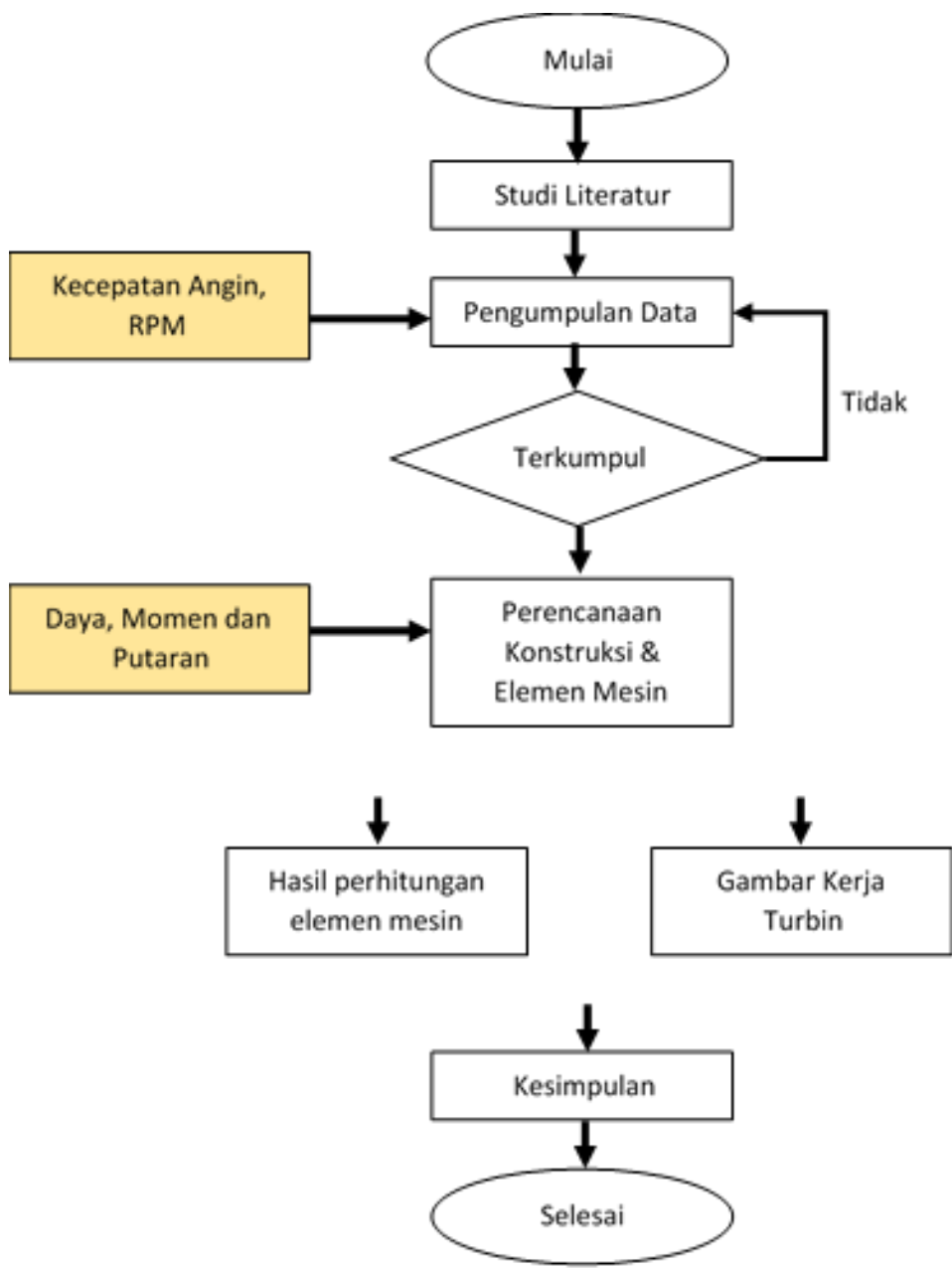

Gambar 3. Diagram alir penelitian

\section{PEMBAHASAN}

\section{Hasil Rancangan}

Hasil rancangan turbin angin sumbu vertikal type Darrieus adalah sebagai berikut:

1. Rangka, berbentuk meja persegi agar dapat menahan getaran dari putaran turbin. Menggunakan material baja profil L ukuran 40x40.

2. Bearing, terdiri dari 2 jenis yaitu Tappered Roller Bearing pada bagian bawah sebagai penahan beban dan Deep Groove Ball Bearing di bagian atas sebagai penyeimbang.

3. Poros Turbin, menggunakan material ST-42 dengan dimensi dan diameter yang disesuaikan pada tegangan serta beban puntir yang diterima.

4. Piringan penjepit, menggunakan material baja plat $5 \mathrm{~mm}$ dengan diameter luar 200mm.

5. Lengan sudu, menggunakan material baja plat $5 \mathrm{~mm}$. dengan panjang $500 \mathrm{~mm}$.

6. Sudu berbentuk airfoil NACA 2415 dengan panjang chord $30 \mathrm{~cm}$ dan tinggi $1000 \mathrm{~mm}$, Menggunakan material Stainless Steel, Garvanize dan seng pada selimut airfoil. 
7. Transmisi, menggunakan jenis pulley dan belt dengan rasio kelipatan 1:14.

8. Generator, memanfaatkan motor bekas mesin cuci

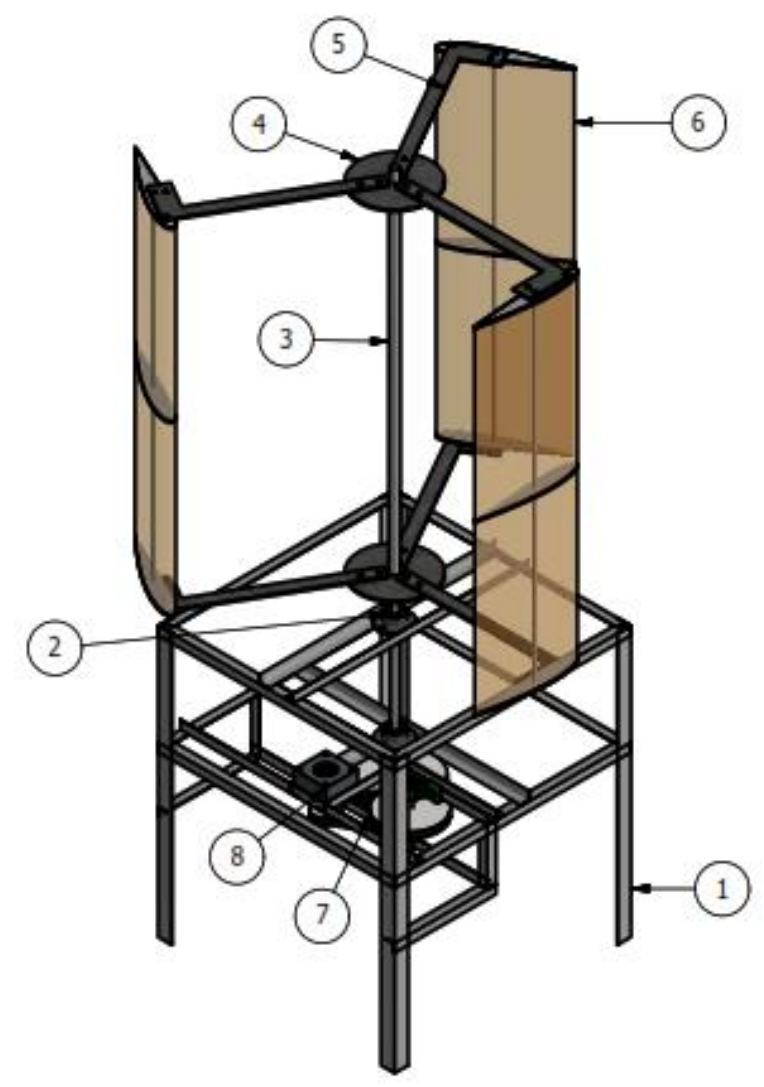

Gambar 6. Rancangan Turbin

\section{Data Perencanaan}

1. Kecepatan angin $(\mathrm{v})=3,5 \mathrm{~m} / \mathrm{s}$

2. Suhu udara saat pengambilan data angin $(T)=30^{\circ} \mathrm{C}$ dengan $\rho=1,225 \mathrm{~kg} / \mathrm{m} 3$

3. Putaran turbin diasumsikan sebesar $30 \mathrm{rpm}$

4. Perbandingan diameter dan tinggi turbin sebesar $1: 1$

5. Daya maksimum yang mampu diserap oleh turbin angin berdasarkan Efisiensi Betz (teori momentum) sebesar $59.3 \%$ dengan persamaan sebagai berikut.

$$
\begin{aligned}
& P_{\text {max }}=\frac{8}{27} \rho A v^{3} \\
& P_{\text {max }}=\frac{8}{27} 1.225 \times 0.785 \times 3.5^{3} \quad P_{\max }=12.216 \text { watt } \\
& \text { dimana }: \\
& P_{\max }=\text { Daya maks. turbin }(\mathrm{Watt}) \\
& \rho=\text { Massa jenis udara }\left(\mathrm{kg} / \mathrm{m}^{3}\right) \\
& A=\text { luas sapuan rotor }\left(\mathrm{m}^{2}\right) \\
& v=\text { Kecepatan angin }(\mathrm{m} / \mathrm{s})
\end{aligned}
$$
watt.

Sehingga daya angin maksimal yang dapat di konversi turbin sebesar 12,1216 


\section{TSR (Tips Speed Ratio)}

Merupakan perbandingan kecepatan tangensial pada ujung sudu terhadap kecepatan angin, yaitu :

$\lambda=\frac{\pi \times n \times D}{v \times 60}$

$\lambda=0,448$

dimana :

$\lambda=$ Tip Speed Ratio

$\mathrm{n}=$ putaran (rpm)

$\mathrm{D}=$ Diameter Rotor $(\mathrm{m})$

$\mathrm{v}=$ Kecepatan angin $(\mathrm{m} / \mathrm{s})$

Dari perhitungan di atas nilai TSR turbin sebesar 0,448.

\section{Momen puntir}

Momen puntir yang akan diterima poros berdasarkan daya yang dikonversi yang dikalikan dengan factor koreksi dihitung dengan persamaan 1 , yaitu :

$P=12,216$ watt $=0,012216 \mathrm{~kW}$

$\mathrm{n}=30 \mathrm{rpm}$

$\mathrm{fc}=1,2$ (faktor koreksi)

$\mathrm{Pd}=\mathrm{fc} \times \mathrm{P}$

$P d=1,2(0,012216)$

$\mathrm{Pd}=0,014659 \mathrm{~kW}$

$\mathrm{T}=9,74 \times 10^{5} \frac{\mathrm{P}_{\mathrm{d}}}{\mathrm{n}_{1}}$

$\mathrm{T}=475.943 \mathrm{~kg} \cdot \mathrm{mm}$

Jadi momen puntir yang diterima poros sebesar $475.943 \mathrm{~kg} . \mathrm{mm}$

\section{Tegangan geser izin}

Menggunakan material ST-42 dengan $\sigma_{B}=42 \mathrm{~kg} / \mathrm{mm}^{2}$ pada poros, maka dihitung nilai tegangan geser izin dengan menggunakan persamaan 2 , yaitu :

$\tau_{a}=\frac{\sigma_{B}}{S f_{1} \times S f_{2}}$

$\tau_{a}=\frac{42}{6 \times 2.5}$

$\tau_{a}=2.8 \mathrm{~kg} / \mathrm{mm}^{2}$

Jadi tegangan geser yang diijinkan adalah sebesar $2,8 \mathrm{~kg} / \mathrm{mm}^{2}$

\section{Diameter Poros}

Menggunakan material ST-42 dengan nilai keamanan $\mathrm{Kt}=3$ (Beban Kejutan atau tumbukan) dan $\mathrm{Cb}=2,6$ (Faktor kemungkinan beban lentur), diperoleh diameter poros dengan menggunakan persamaan 3, yaitu :

$d_{s}=\left[\left(\frac{5,1}{\tau_{a}}\right) \cdot K_{t} \cdot C_{b} \cdot T\right]^{\frac{1}{3}}$ 


$$
\begin{aligned}
& d_{1}=\left[\left(\frac{5,1}{2,8}\right) \times 3 \times 2,6 \times 475,943\right]^{\frac{1}{3}} \\
& d_{1} \geq 18,9 \mathrm{~mm}
\end{aligned}
$$

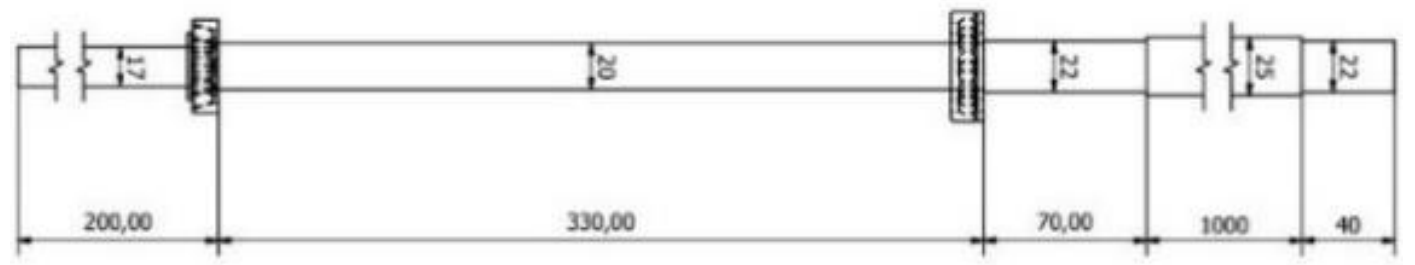

Gambar 7. Poros Turbin

Diameter minimal poros turbin sebesar $18,9 \mathrm{~mm}$.

\section{Bantalan}

Menggunakan bantalan jenis Tappered roller bearing dan deep groove ball bearing untuk menahan beban vertikal dan puntiran turbin. Gaya dan beban yang bekerja dapat dilihat pada Gambar 8.

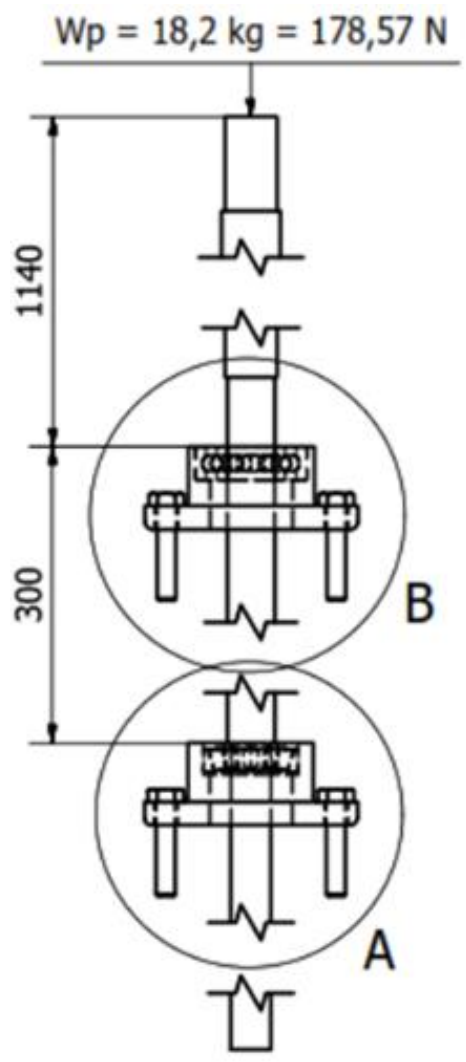

Gambar 8. Analisa Gaya beban Poros

Berdasarkan prinsip kesetimbangan diperoleh beban pada tiap bantalan yang digunakan, sebagai berikut.

$\in M_{A}=0$

$R_{B}(\mathrm{AB})-\mathrm{Wp}(\mathrm{d} / 2)=0$

$R_{B}(330)-18,2(25 / 2)=0$ 


$$
\begin{aligned}
& R_{B}=\frac{227,5}{330}=0,75 \mathrm{~kg} \\
& \in F_{y}=0 \\
& R_{A}+R_{B}-W_{P}=0 \\
& R_{A}=W_{P}-R_{B} \\
& R_{A}=18,2-0,75=17,45 \mathrm{~kg} \\
& \mathrm{R}_{\mathrm{A}}=17,45 \mathrm{Kg}=171 \mathrm{~N} \\
& \mathrm{R}_{\mathrm{B}}=0,2 \mathrm{Kg}=7,35 \mathrm{~N}
\end{aligned}
$$

Sehingga diperoleh resultan gaya radial $\mathrm{Fr}$ untuk keamanan konstruksi sebesar $\mathrm{FR}=\mathrm{RA}=171 \mathrm{~N}$. Sedangkan resultan gaya aksial sebesar $F A=W P=18,2 \mathrm{~kg}=178,57 \mathrm{~N}$.

\section{Penentuan beban ekuivalen}

Untuk memperkirakan umur bantalan dihitung beban ekuivalen berdasarkan jenis bantalan yang digunakan.

1. Bearing $\mathrm{A}$

$X=0,4$ (untuk jenis bantalan Roller)

$F_{R}=171 \mathrm{~N}$

$Y_{A}=1.7$

$F_{A}=178,57 \mathrm{~N}$

$K_{S}=2$

$P=\left(X \cdot F_{R} \cdot v+Y_{A} \cdot F_{A}\right) \cdot K S$

$P=(0.4 \times 171+1,7 \times 178,57) \times 2$

$P=743,938 \mathrm{~N}$

$L=\left(\frac{C_{r}}{P}\right)^{3} \times 10^{6}$

$L=\left(\frac{1990}{743,938}\right)^{3} \times 10^{6}$

$L=1,9 E^{+7}$ Putaran

$L_{H}=\frac{L}{60 \times n}$

$L_{H}=\frac{1,9 E^{+7}}{60 \times 30}$

$L_{H}=10.555 \mathrm{Jam}$

$L_{H}=439,79$ Hari

2. Bearing $B$

$X=1$ (untuk jenis bantalan Bola)

$F_{R}=171 \mathrm{~N}$

$Y_{B}=0.5$

$F_{A}=178,57 \mathrm{~N}$

$K_{S}=1,5$ 


$$
\begin{aligned}
& P=\left(X . F_{R \cdot} \cdot v+Y_{B} \cdot F_{A}\right) \cdot K s \\
& P=(1 \times 171+0,5 \times 178,57) \times 1,5 \\
& P=390,4275 N \\
& L=\left(\frac{C_{r}}{P}\right)^{3} \times 10^{6} \\
& L=\left(\frac{6550}{390,4275}\right)^{3} \times 10^{6} \\
& L=4,721 E^{+9} \text { Putaran } \\
& L_{H}=\frac{L}{60 \times n} \\
& L_{H}=\frac{1,8409637 E^{+11}}{60 \times 30} \\
& L_{H}=26.227 \mathrm{Jam} \\
& L_{H}=1092 \text { Hari }
\end{aligned}
$$

Perkiraan umur bantalan selama 439 hari untuk bantalan roller dan 1092 hari untuk batalan bola.

\section{Rasio Trasmisi}

Untuk menaikan putaran dari turbin ke generator digunakan transmisi dengan rasio $1: 12$.
a. $\quad \mathrm{N} 1=30 \mathrm{rpm}$
b. Diameter pulley penggerak
$\left(d_{1}\right)=8$ in $=203,2 \mathrm{~mm}$

c. Diameter pulley perantara
$\left(d_{2}\right)=2$ in $=50,8 \mathrm{~mm}$
$\left(d_{3}\right)=6$ in $=152,4 \mathrm{~mm}$

d. Diameter pulley generator $\left(d_{4}\right)=2$ in

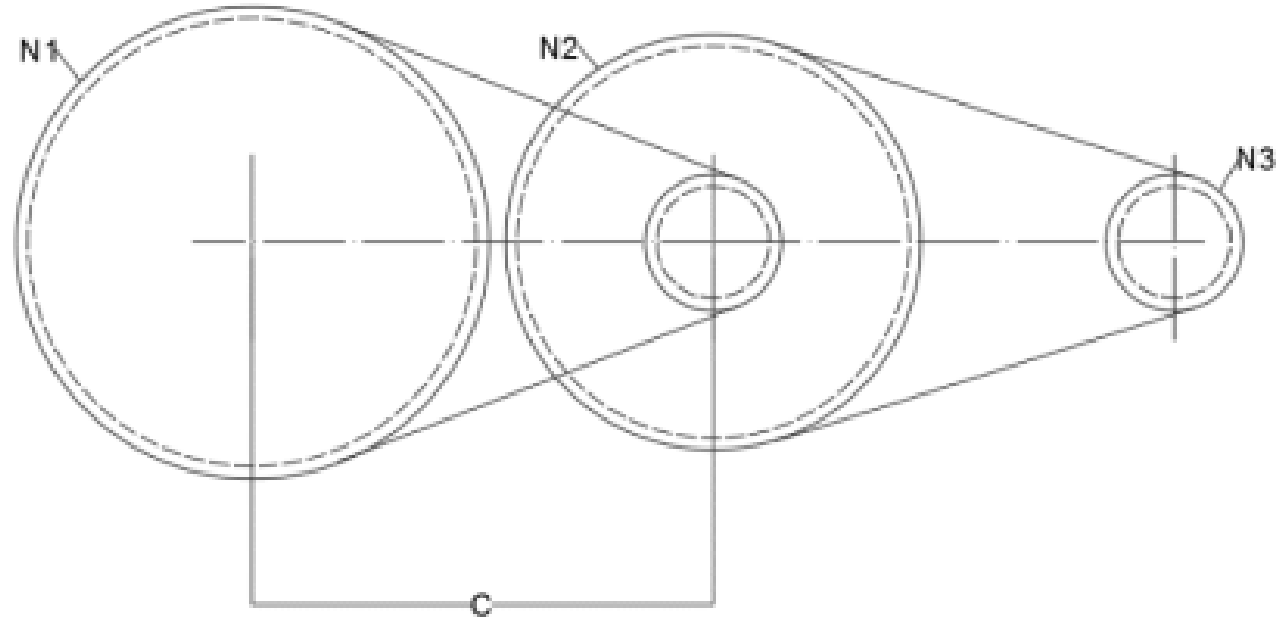

Gambar 9. Transmisi 


\section{Perencanaan Sabuk V}

Penggunaan transmisi jenis sabuk perlu diketahui momen, panjang dan jarak sumbu poros antar transmisi.

1. Momen Poros Transmisi

$T=9,74 \times 10^{5} \times \frac{P}{n_{1}}$

$T_{2}=9,74 \times 10^{5} \times \frac{0.014659}{120}$

$T_{2}=118.985 \mathrm{~kg} \cdot \mathrm{mm}$

$T_{3}=9,74 \times 10^{5} \times \frac{0.014659}{420}$

$T_{3}=33.995 \mathrm{~kg} . \mathrm{mm}$

2. Panjang Sabuk Keliling

$L=2 C+\frac{\pi}{2}\left(D_{p 1}+d_{p 1}\right)+\frac{1}{4 C_{1}}\left(D_{p 1}-d_{p 1}\right)^{2}$

$L_{1}=903,6 \mathrm{~mm}=35,5 \mathrm{in}$

$L_{2}=567,2 \mathrm{~mm}=22,3 \mathrm{in}$

3. Jarak Sumbu Poros

$b=2 L-3,14\left(D_{p}+d_{p}\right)$

$b_{1}=797.56 \mathrm{~mm}$

$b_{2}=638,048 \mathrm{~mm}$

$C=\frac{b+\sqrt{b^{2}-8\left(D_{p}-d_{p}\right)^{2}}}{8}$
$C_{1}=183,57 \mathrm{~mm}$
$C_{2}=150,96 \mathrm{~mm}$ 


\section{Rangka}

Menggunakan material Baja Profil L $40 \times 40$ berbentuk meja dengan dimensi luas $700 \times 700 \mathrm{~mm}$ dan tinggi $800 \mathrm{~mm}$.

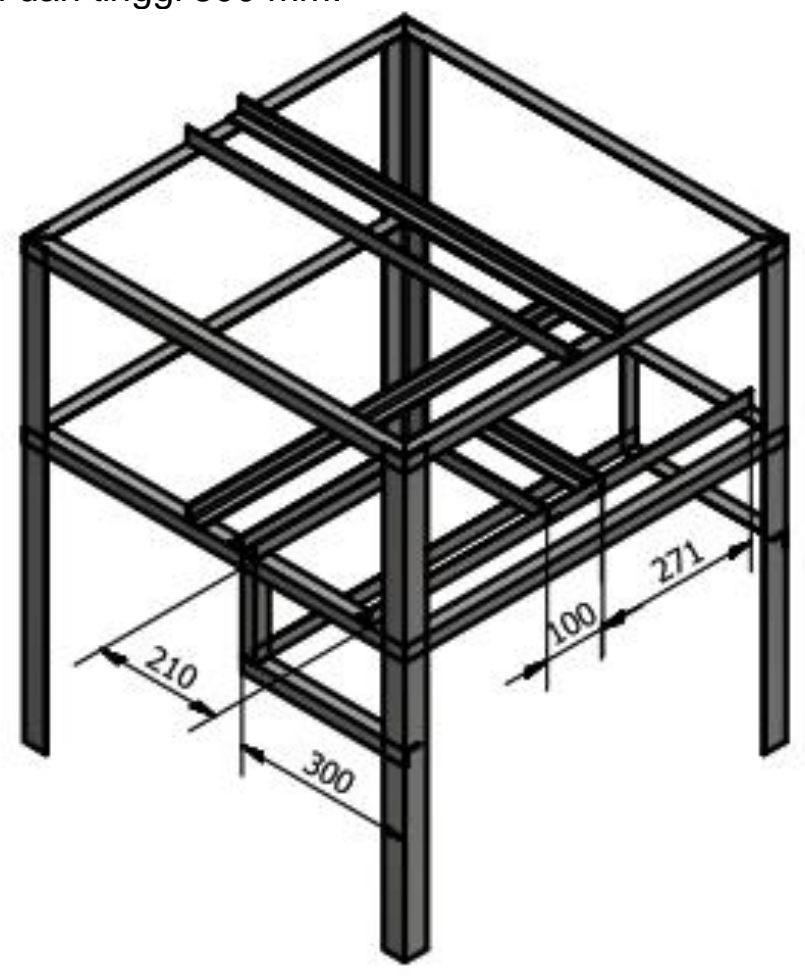

\section{Part List}

\section{Gambar 10. Rangka}

Keseluruhan komponen atau part dari turbin angin sumbu vertikal type Darrieus dapat dilihat pada table di bawah ini.

Tabel 3. Part list

\begin{tabular}{|c|c|l|l|}
\hline \multicolumn{4}{|c|}{ PARTS LIST } \\
\hline ITEM & QTY & \multicolumn{1}{|c|}{ PART NUMBER } & \multicolumn{1}{|c|}{ DESCRIPTION } \\
\hline 1 & 1 & Rangka & Profil L 40x40 \\
\hline 2 & 1 & SKF 6204 N & $\begin{array}{l}\text { Deep groove ball } \\
\text { bearings single row with } \\
\text { snap ring groove SKF }\end{array}$ \\
\hline 3 & 1 & SKF 30203 & $\begin{array}{l}\text { Tapered roller single } \\
\text { row bearings SKF }\end{array}$ \\
\hline 4 & 1 & Poros Turbin & ST-42 \\
\hline 5 & 2 & Piringan Penjepit & Baja Plat 5mm \\
\hline 6 & 3 & Lengan Sudu & Baja Plat 5mm \\
\hline 7 & 3 & Airfoil & NACA 2415-30mm \\
\hline 8 & 2 & AST_Bearings_UCP201 & \\
\hline 9 & 1 & Transmisi & Pulley dan Belt \\
\hline
\end{tabular}




\section{KESIMPULAN}

Kesimpulan dari penelitian ini, yaitu turbin angin sumbu vertikal dirancang dengan diameter dan tinggi masing-masing 1 meter menggunakan 3 buah sudu berbentuk airfoil type NACA 2415 dengan panjang chord $30 \mathrm{~cm}$. Diameter minimal poros yang digunakan sebesar 19,83 mm. Diameter poros bertingkat menjadi $17 \mathrm{~mm}$ sepanjang $220 \mathrm{~mm}, 20 \mathrm{~mm}$ sepanjang $330 \mathrm{~mm}, 22 \mathrm{~mm}$ sepanjang $70 \mathrm{~mm}, 25 \mathrm{~mm}$ sepanjang $1000 \mathrm{~mm}$ dan $22 \mathrm{~mm}$ sepanjang $40 \mathrm{~mm}$. Bantalan yang digunakan adalah tappered roller bearing nomor 30203 dan deep groove ball bearing nomor 6204. Menggunakan puli dengan diameter luar 8 in (203.2 mm), 6 in (152.4 mm) dan 2 buah pulley 2 in $(50.8 \mathrm{~mm})$. Belt menggunakan merk VPower dengan NO.35 dan NO.26. Menggunakan poros perantara dengan diameter $14 \mathrm{~mm}$. Rasio kenaikan putaran sebesar 1:12. Rangka menggunakan baja profil $L$ ukuran $30 \times 30$ dengan total keseluruhan $15050,8 \mathrm{~mm}( \pm 15 \mathrm{~m})$.

\section{DAFTAR PUSTAKA}

Assauri, Sofyan. 1993. Manajemen Arsyad, A.M dan Hartono. F. 2009. Pembuatan Kode Desain Dan Analisis.

Daryanto, Y. 2007. Kajian Potensi angin Untuk Pembangkit Listrik Tenaga Bayu. Balai PPTAGG - UPT - LAGG. Yogyakarta.

Ula, M dkk. 2013. Perancangan Konstruksi Turbin Angin di Atas Hybrid Energi Gelombang Laut. Jurnal Teknik Pomits Vol. 3, No. 2. Jurusan Teknik Sistem Perkapalan, Fakultas Teknologi Kelautan, Institut Teknologi Sepuluh Nopember, Surabaya.

Rachman. A. 2012. Analisis Dan Pemetaan Potensi Energi Angin Di Indonesia. Skripsi Program Studi Teknik Mesin, Fakultas Teknik Universitas Indonesia.

Suhemi. 2016. Perancangan Turbin Angin Type Savonius Multi Blade Skala Laboratorium Dengan Kecepatan Angin Rendah. Skripsi Program Studi Teknik Mesin Fakultas Teknik Universitas Lambung Mangkurat.

Sularso dan Kiyokatsu Suga. 2004. Dasar Perencanaan dan Pemilihan Elemen Mesin. Jakarta. PT. Pradnya Paramita. 